\title{
The innovative solutions in new building for education architects in Lublin
}

\author{
Jan Wrana ${ }^{1}$, Agnieszka Fitta ${ }^{2}$ \\ ${ }^{1}$ Independent Architectural Lab, Faculty of Building and Architecture, \\ Lublin University of Technology, e-mail: janwrana@architekci.pl \\ ${ }^{2}$ Phd student of Faculty of Architecture, Cracow University of Technology, \\ Design OfficeJW-Proinvest, e-mail:agnieszka.fitta@doktoranci.pk.edu.pl
}

\begin{abstract}
The article provides a few new and innovative system solutions a realized extension of the DB\&A of Lublin University of Technology called Eastern Innovation Centre of Architecture. The object is "an integrating zone of practical education." The form of the spatial sculpture of object was achieved via significant overhanging of the assembly hall accommodating 200, supported by the slanted wall, coming from the line of the facade and three cubic elements firmly in the construction of the building. The interior patio emphasizes "the unity of the aims of open education" and also provides additional light for the exhibition space. The mobility of the interior divisions allows "flexible shaping of functional divisions". The external shutters being electronically controlled, in particular sections on the facade allow for "interactive participation" of the users in the aesthetic creation of the facade. In case of strong winds the external shutters are shut automatically.
\end{abstract}

Keywords: innovation, Lublin, Eastern Innovation Centre od Architecture.

\section{Introduction}

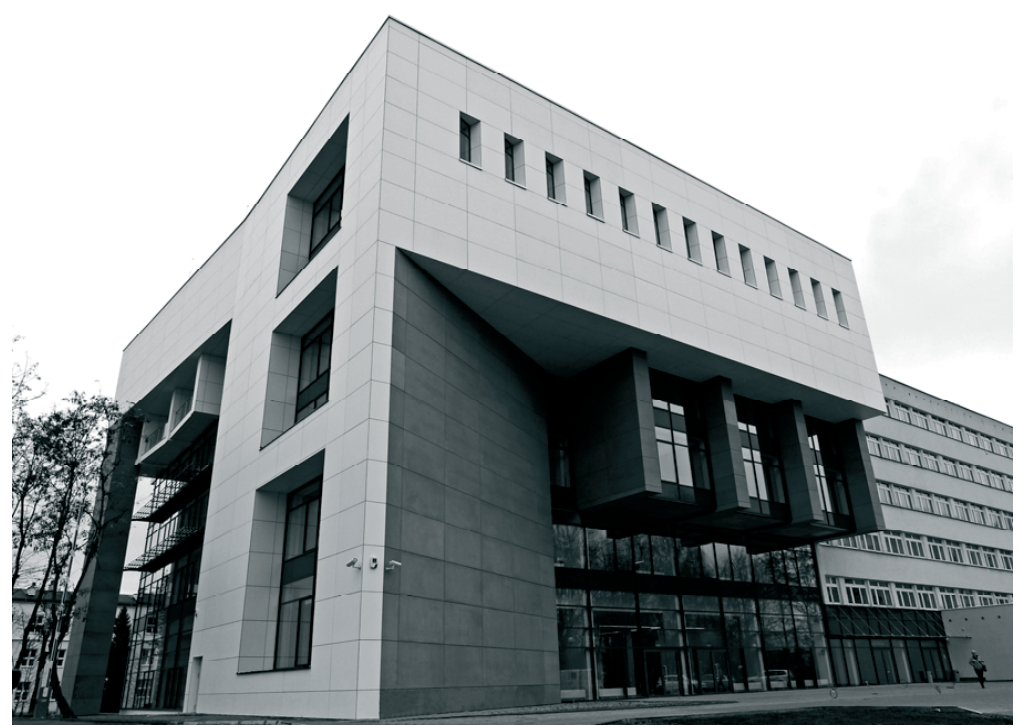

Fig. 1. Eastern Innovation Centre of Architecture - a general view. Photo by K. Gnat. 
Eastern Innovation Centre of Architecture is a new wing of the Civil Engineering and Architecture Faculty of Lublin University of Technology, designed for the students of architecture. A seemingly simple, subtly sculptured block, vividly corresponds with and perfectly fits in the complex of the university buildings realized in Polish postmodernism, developed in the 1970s.

The building was built in 2010-2013, using the European Union funds from the "East Poland Development" program. The team of architects and builders (among others Jan Wrana - the head of the Project and the chief designer of the investment, Bartłomiej Kwiatkowski - the co-author of the concept, Metropolis-Redan - the co-authors of the construction and executive designs, BUDIMEX S.A. - the chief contractor) succeeded in performing both fast and efficiently. ${ }^{1}$

\section{Innovative solutions}

\subsection{Construction}

The building of the Eastern Innovation Centre of Architecture, located in the premises of Lublin University of Technology campus, by its form of "spatial sculpture", corresponds with the spatial composition of the complex of the university buildings located along Nadbystrzycka Street. The building itself is characterized by simple yet elegant architecture, the quality of which was achieved among others via precisely made facade.

The form of the spatial sculpture was achieved via significant overhanging of the assembly hall accommodating 200 people (on the fourth and fifth floor) supported by the slanted wall, coming from the line of the facade and three cubic elements firmly anchored in the construction of the building.

The interior spacious patio emphasizes "the unity of the aims of open education" in the academic environment and also provides additional light for the exhibition space in the main hall on the ground floor. It is both a place for exhibiting students' work (on the ground floor) and the place for students' activity - a meeting place or a place where one can share thoughts and experiences with the others.

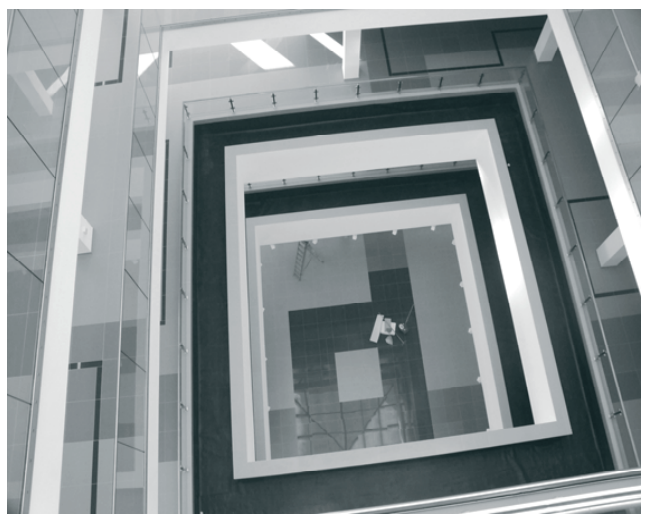

Fig. 2. The patio. Photo by J. Wrana.

\footnotetext{
1 The design consultants: professor Bogusław Szmygin (The Dean of the Civil Engineering and Architecture Faculty of Lublin University of Technology 2006-2012), professor Andrzej Getter - a sculptor of the Academy of Fine Arts.
} 


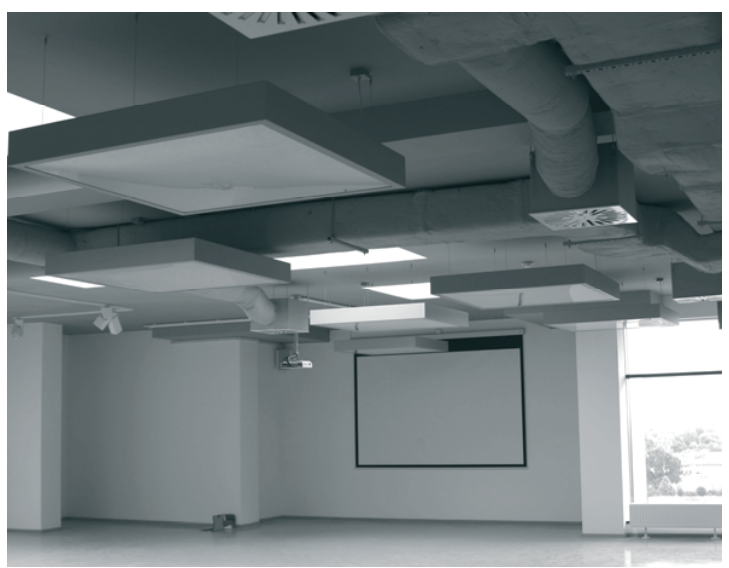

Fig. 3. A drawing room - the technical ceiling. Photo by J. Wrana.

\subsection{The ceilings}

The ceilings applied in the building give an impression of being unfinished, however, leaving out smooth finish was an intentional and well-thought decision made by the designers.

Due to the fact that the mechanical ventilating ducts and aesthetically made installations are uncovered, the future architect-designer can broaden their knowledge as far as the need for interbranch co-operation is taken into account. The students by means of observation, may it be unintentionally and subconsciously, get accustomed to technical aspects of designing and remember them. Due to this fact it is more possible that they will appreciate the effects of the coherent and effective co-operation between an architect and discipline-specific designers without which it is not possible to design a building that will be both architecturally and technically perfect.

At the same time the installation paths thanks to the proper finish and conduct are a peculiar and original decoration that draws attention of both users and viewers not connected with architecture.

\subsection{The walls with Le Corbusier's pictograms}

A total innovation, first of all because of the functional aspect - is located on the third floor. The designers decided to separate the faculties and institutions from the hall open for general use by means of glass walls by MARS company.

Two kinds of glazing were applied: transparent (between the hall and the interior corridor) and frosted (between the corridor and the rooms of the faculties). The first - smooth glass - is ornamented with the pictograms based on the drawings by the most famous architect of the $20^{\text {th }}$ century - Le Corbusier. They present human shapes in various poses - it is Modulor, the architect's hallmark, "the measure" he created that helps in designing.

The frosted glass is a compromise satisfying both the workers who will have comfort and privacy and the students who will be able to see whether anybody is inside or not. 
The concept of glazing is a vivid reference to the theme of integration - the lack of the visible divisions - the idea of onespatiality - is favourable for both the visual integration of the place, and the integration between the workers and the students.
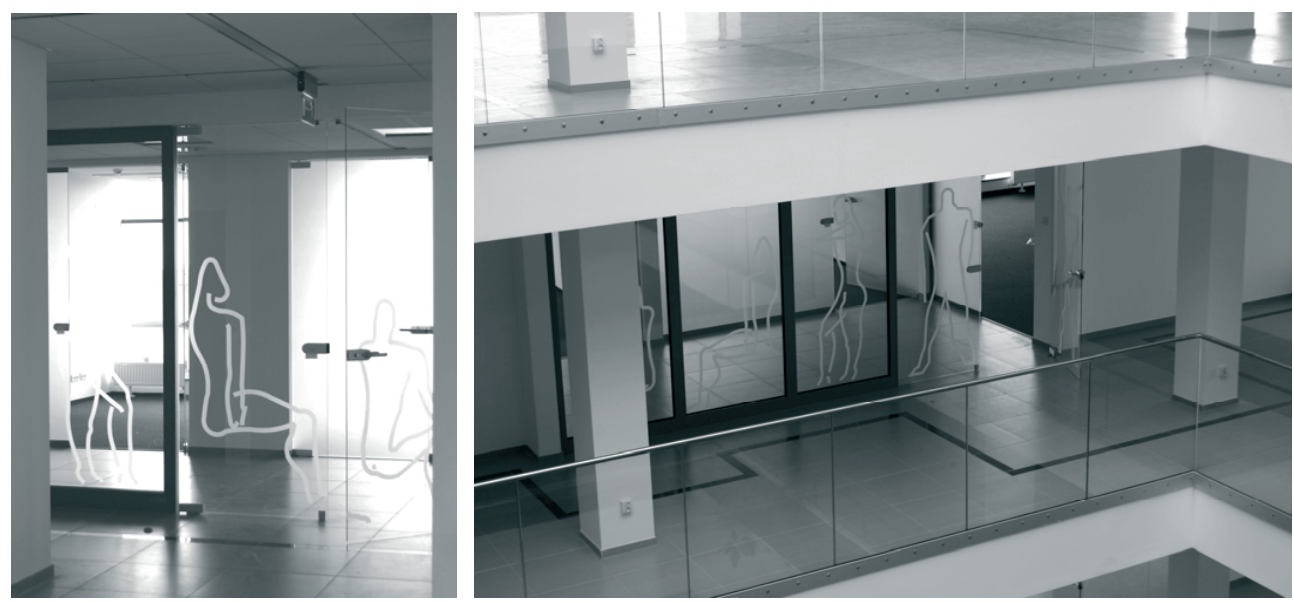

Fig. 4,5. The walls by MARS with Le Corbusier's pictograms. Photo by J. Wrana.
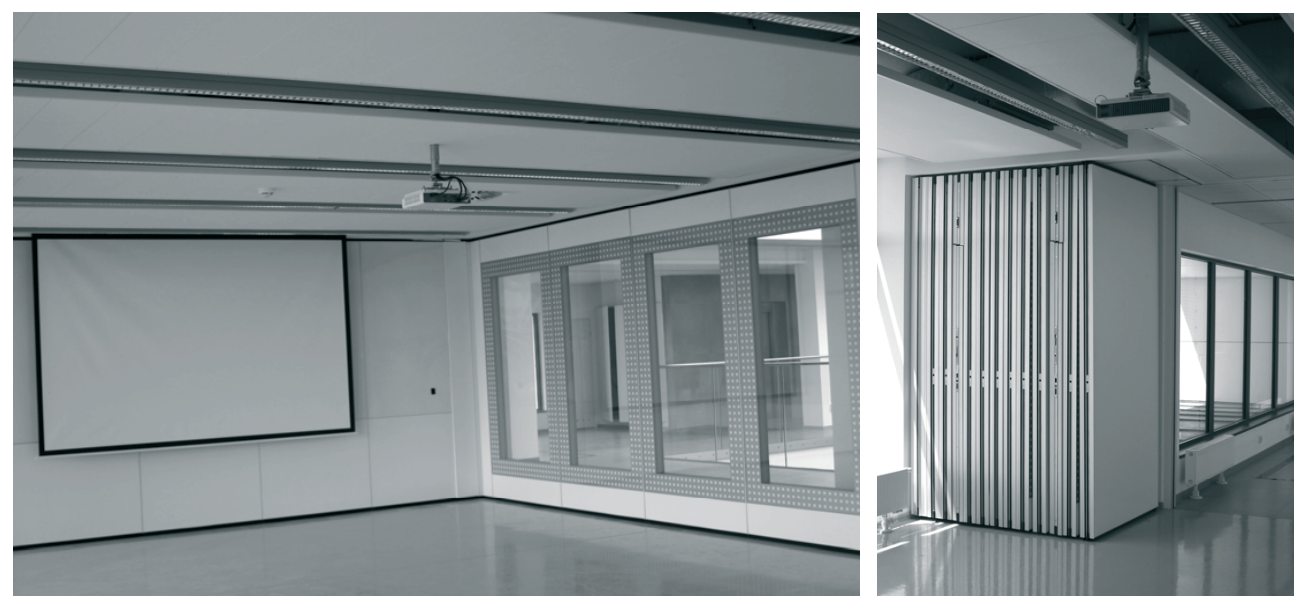

Fig. 6,7. The mobile divisions on the fourth floor - extended and retracted. Photo by J. Wrana.

\subsection{The mobile divisions}

In certain parts of the building - on the fourth and fifth floor- the interior mobile divisions were applied. They allow for separating the hall from the classrooms and, at the same time, the mobility of the interior divisions allows for the "flexible shaping of functional divisions".

The mentioned divisions are the most distinctive elements of the floors both visually and functionally. Thanks to them the space is more flexible - it allows for various arrangements and changes, it can be transformed as needed.

The rooms can have various functions. In case of a large number of students, for instance during the overview - everybody can gather in one room, whereas when 
necessary, it can be divided for smaller groups assigned to assistant professors, making small, private rooms that will provide comfortable work without any interference and disturbances. They can also be used during conferences as seminar rooms or exhibiting rooms, or as rooms for preparation before defences, overviews, etc.

\subsection{The external shutters}

Because of the considerable amount of glazing on the south-east and south-west facade, and the risk of the building overheating, external shutters were applied.

They allow for regulation of the amount of light, thus they protect the building against excessive overheating. They also form a protection against wind, in case of strong wind the external shutters are shut automatically. They are divided into sections and they are electronically controlled by means of the system that allows to shut them with one move and to control them in various sections, which, in turn, allows for "interactive participation" of the users in the aesthetic creation of the facade by opening and shutting them.

The shutters also play an aesthetic role - they make the calm, glazed facades more attractive, due to their being "a technical detail." Both when open or shut, they make an attractive part of the facade- literally enlivening it because it is thanks to them that the building can change its image.

Regulating the external shutters, the partial or the whole opening or shutting them make new compositions each and every time they are moved, compositions being a mixture of various facade materials: beige-cream modular facade plates covering the space - the navy blue modular segments in aluminium construction and alternately shut segments of the glazed facade depending on the part of the day and the amount of sunlight.
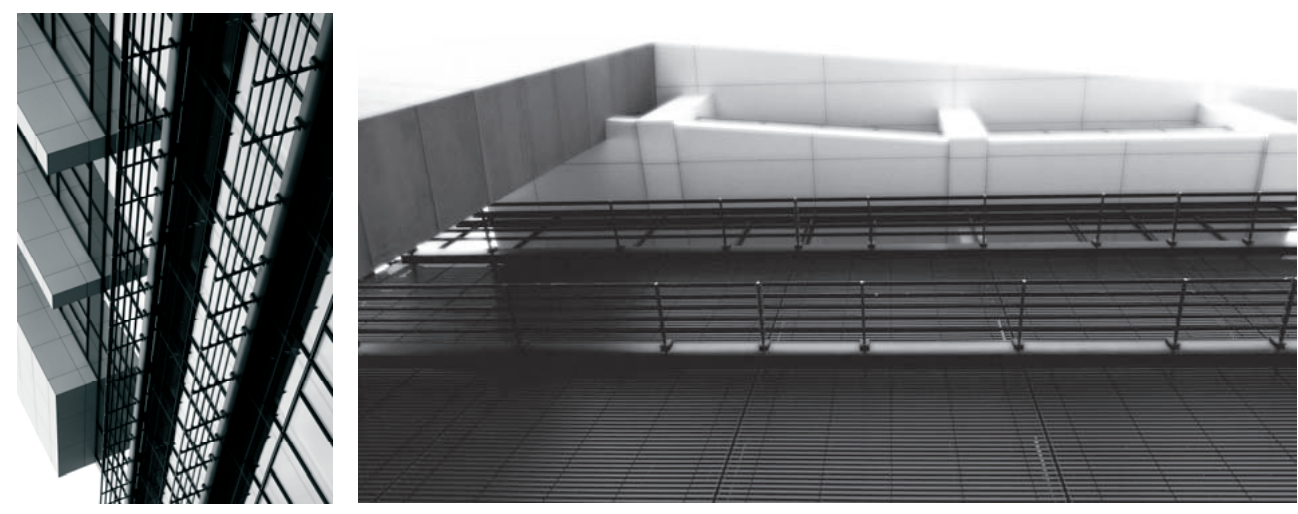

Fig. 8,9. The external shutters. Photo by K. Gnat.

\section{Summary}

A number of innovative solutions were applied in the Eastern Innovation Centre of Architecture in Lublin, which make the comfort of using the building and its quality higher. At the same time, during the designing phase, the context of the place was not forgotten. The new building was adapted to the existing environment, making the building extremely modern but blending with the spirit of the place. 
The building located by the main entrance to the University campus was an attraction even at the stage of construction, it already showed its visible, but not aggressive modern form, in an aware way respecting the context of the place.

The realized building connects the latest technologies with the respect towards the past, thus creating a comfortable working and learning place.

\title{
Bibliography
}

[1] Barnaś J. Elewacje dynamiczne - kształtowanie nowoczesnych elewacji - dobór technologii i materiałów. Czasopismo Techniczne PK, zeszyt 11, 2-A/1/2011, Kraków 2011, s. 7-13.

[2] Dworzak-Żak E. Ściany zewnętrzne nowej generacji - aktywne, interaktywne, medialne. Czasopismo Techniczne PK, 4-A/1/2007, Kraków 2007, s. 43-50.

[3] Helenowska-Peschke M., Interaktywność - nowa filozofia architektury, Czasopismo Techniczne PK, z. 7-A/2, Kraków 2010, s.119-124.

[4] Tymkiewicz J. Systemy osłon przeciwsłonecznych - wady i zalety różnych rozwiązań. Czasopismo Techniczne PK, Zeszyt 11, 2-A/2/2011, Kraków 2011, s. 213-220.

[5] Wrana J. Eseje o tożsamości miejsca. Wybrane artykuły dotyczace tożsamości i kontekstu. Wydawnictwo Politechniki Lubelskiej, Lublin 2012.

[6] Wrana J. Tożsamość miejsca. Kryterium $w$ projektowaniu architektonicznym. Wydawnictwo Politechniki Lubelskiej, Lublin 2011.

\section{Przykłady innowacyjnych rozwiązań w nowym obiekcie dla kształcenia architektów w Lublinie}

\author{
Jan Wrana ${ }^{1}$, Agnieszka Fitta ${ }^{2}$ \\ ${ }^{1}$ Politechnika Lubelska, Wydziat Budownictwa i Architektury, \\ Samodzielna Pracownia Architektoniczna, e-mail: janwrana@architekci.pl \\ 2 doktorantka Wydziatu Architektury Politechniki Krakowskiej, \\ Biuro ProjektoweJW-Proinvest, e-mail: agnieszka.fitta@doktoranci.pk.edu.pl
}

Streszczenie: Artykuł przedstawia kilka nowych, innowacyjnych rozwiązań systemowych w zrealizowanej rozbudowie WBiA Politechniki Lubelskiej - „WICA” - Wschodnie Innowacyjne Centrum Architektury. Obiekt jest „integracyjną strefą praktycznej edukacji”. Formę rzeźby przestrzennej obiektu uzyskano poprzez znaczne nadwieszenie auli przeznaczonej dla 200 osób, opartej na skośnej ścianie, wyprowadzonej z linii rysunku elewacji, oraz trzech kubicznych elementach, zakotwionych w konstrukcji obiektu. Wewnętrzne patio podkreśla „wspólnotę celów kształcenia otwartego" oraz doświetla przestrzeń ekspozycyjną,. Mobilność podziałów wewnętrznych umożliwia „elastyczne kształtowanie podziałów funkcjonalnych". Elektroniczne sterowanie zewnętrznymi żaluzjami w poszczególnych sekcjach na elewacjach pozwala na ,interaktywne uczestnictwo” użytkowników w estetycznym kształtowaniu elewacji. W sytuacjach natężeń wiatrów żaluzje są automatycznie zsuwane.

Słowa kluczowe: innowacja, Lublin, Wschodnie Innowacyjne Centrum Architektury. 